Article Type: Research Paper

\title{
The Impact of Population Density and Economic Growth on Environmental Quality: Study in Indonesia
}

\author{
Abdulloh Nashiruddin Wafiq and Suryanto*
}

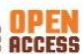

\section{AFFILIATION:}

Department of Economics, Faculty of Economics and Business,

Universitas Sebelas Maret, Central Java, Indonesia

\section{*CORRESPONDENCE:}

suryanto_feb@staff.uns.ac.id

THIS ARTICLE IS AVALILABLE IN:

http://journal.umy.ac.id/index.php/esp

DOI: 10.18196/jesp.v22i2.10533

\section{CITATION:}

Wafiq, A.N., \& Suryanto, S. (2021). The Impact of Population Density and Economic Growth on Environmental Quality: Study in Indonesia. Jurnal Ekonomi \& Studi Pembangunan, 22(2), 301-312.

\section{ARTICLE HISTORY}

Received:

04 Dec 2020

Revised:

02 Jul 2021

$16 \mathrm{Jul} 2021$

02 Aug 2021

Accepted:

16 Sep 2021

\begin{abstract}
Sustainable economic growth is followed by an improvement in environmental quality. The purpose of this study is to identify the correlation between economic growth and population density on the environmental quality index (EQI) in Indonesia. In addition, it also aims to determine the impact of economic growth and population density on the environmental quality Index. This study uses a quantitative method with secondary data from 33 provinces in Indonesia from 2010 to 2016. Data were analyzed using Pearson correlation and panel data regression. The result showed that the correlation between economic growth and population density on the quality of the environment was moderate. It has a significant negative impact on environmental quality.

Keywords: Economic Growth; Population Density; Environmental Quality Index

JEL Classification: F43; O47; R23; P23; Q56; K32
\end{abstract}

\section{Introduction}

Various demands to attain high economic growth are frequently misleading for third-world countries seeking prosperity. The Sustainable Development Goals (United Nations, 2017) hints that third-world countries have not yet implemented sustainable development standards. For development purposes, environmental quality is often overlooked. Besides, sustainable development goals frequently contradict strategies in pursuing economic growth.

The environmental quality should improve after a period of rapid economic growth, or at least, the environmental degradation impacts are not severe. However, in many cases, the pursuit of rapid economic growth has had a negative impact on environmental quality. Several studies have confirmed the existence of a negative relationship between environmental quality and economic growth. The results validated Simon Kuznets's research, which is known for the Environmental Kuznets Curve or the inverted U-curve. It illustrates that deal between the economic growth and the quality of environment will occur. In the early stages, the growth may reduce environmental quality (Lee \& Oh, 2015), (Damayanti \& Chamid, 2016); and (Bouznit \& Pablo-Romero, 2016). Research conducted by Yustisia and Sugiyanto (2014) also concludes that the EKC is valid, although it only applies in middle-income countries. 


\section{Wafiq \& Suryanto \\ The Impact of Population Density and Economic Growth ...}

On the other hand, research by Ong and Sek (2013) yields contradictory results. This research reveals that economic growth had no significant impact on environmental quality in low and middle-income countries. There are no empirical proofs that show the connection between economic growth and increased carbon emissions in Turkey (Ozturk \& Acaravci, 2010).

Regarding the two previously mentioned arguments, this present study seeks to investigate the relationship between population density and economic growth, and environmental quality in Indonesia. Further, this study will generate a relationship pattern that supports one of the two opinions, whether it supports the first opinion or the second opinion.

Aside from those aims, several underlying principles have led to the emergence of this study. First, the quality of the environment as an important factor in sustainable economic growth has been extensively studied by the international community from various agencies concerned with the survival of the future. The environmental quality which is proxied from the Environmental Quality Index (EQI) is a relatively new concept in Indonesia. This measure was first coined in 2009. EQI is a national environmental management performance index that employs the concept of the Environmental Performance Index (EPI) by incorporating several criteria covering air quality, water quality, and forest cover quality.

Second, in the traditional context, development is interpreted as a country's attempt to improve its people's quality of life (Todaro \& Smith, 2015), which is a national economy's ability to create, maintain and even increase GNI (Gross National Income) or GDP (Gross Domestic Product) for long-term (Todaro \& Smith, 2011). Economic growth can be defined as a steady increase in income over time. For years, various efforts have been made to accelerate economic growth. However, current economic growth has impacted our environment in negative ways. Environmental issues have emerged as a major problem in today's life. Environmental problems are caused by several factors, one of which is environmental degradation caused by complex human activities.

As described by the mutual connections between development and its surroundings, environmental problems can jeopardize the development goal. This condition raises two consequences. First, development goals can be seen from improved environmental quality that is part of improving welfare. However, if health and quality of life are sacrificed for the sake of economic growth, which causes high pollution in the environment, it cannot be considered development. Second, the decrease in output in the future is a result of environmental damage that affects productivity (Beckerman, 1992) and (Hitam \& Borhan, 2012).

This study applied the panel data method, which was adopted from the method used by Yustia and Sugianto (2014), Mor and Jindal (2017), and Jindal et al. (2012). Panel data method is multi-dimensional data that combines cross-sectional data and time series (between spaces or individuals) (Gujarati \& Porter, 2009). In addition, this study also 
employed correlation analysis to find out how strong the relationships between variables are.

The inverted U-curve theory elucidates the relationship between environmental degradation and economic growth level. Furthermore, this theory states that low-income countries tend to focus on efforts to increase state revenue through investment and production that generate higher income, despite issues emerging in the environmental quality. As a result, the pollution level will rise at the beginning of revenue growth, and then fall as the growth continues (Hassan et al., 2015) and (Narayan et al., 2016). However, other studies continue to believe that economic growth will not have a negative impact on environmental quality in the short run (Safriwan \& Idris, 2020); (Ozturk \& Acaravci, 2010).

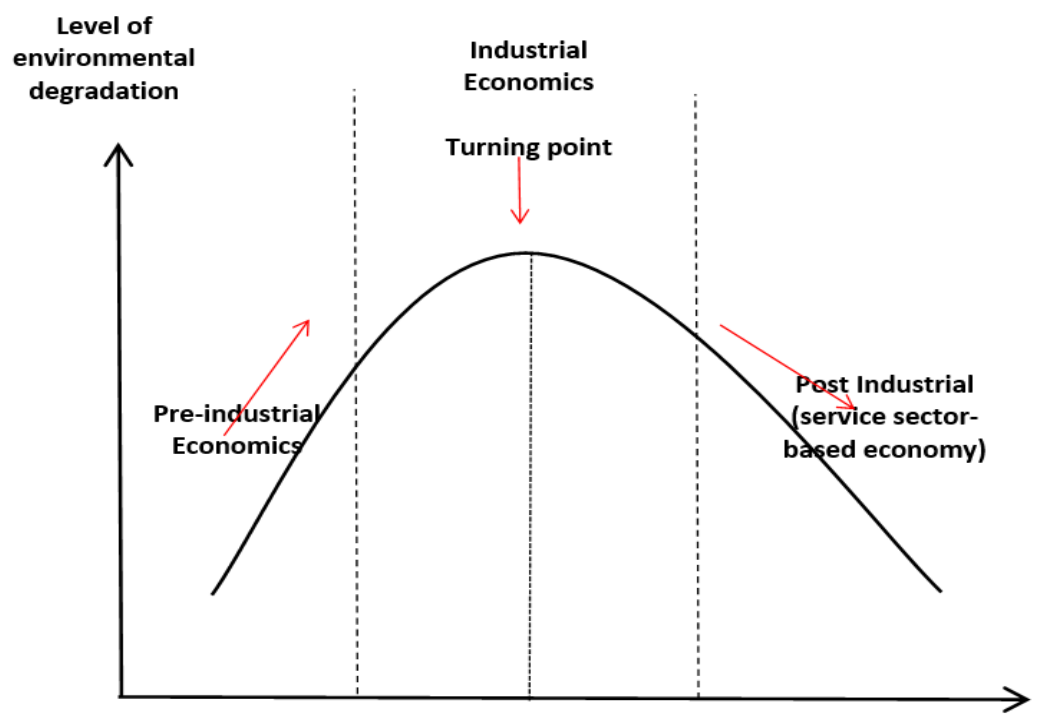

Figure 1 Environmental Kuznets Curve: Locus of State Source: Panayotou, 2003

On the Kuznets curve, the relationship between phases of economic development and environmental degradation is divided into three stages. The first stage of economic growth is characterized by rising environmental damage and degradation or known as pre-industrial economics, then followed by the second stage which is industrial economics, and the third stage is post-industrial economics (service economy) (Panayotou, 2003).

In addition to the debate, other factors may also contribute to environmental quality in each region. One of them is population density which has a positive impact on the decline in environmental quality. It is supported by research conducted by Zuhri in Indonesia (2014) and Ahmad et al. (2005) in Pakistan. The previous research shows that a higher population density in an area has a negative impact on the environmental quality. 


\section{Research Method}

The GRDP and population density data used in this study were obtained from the Statistics Indonesia or BPS (2020). The data of the environmental quality index were derived from the publication of the Ministry of Environment and Forestry. The analysis period used was 2010-2016 in 33 provinces in Indonesia.

To analyze the data, Pearson correlation and multiple regression were performed. Pearson correlation was designed to determine the closeness of the relationship between variables. The Pearson Correlation formulas are as follows:

$$
\begin{aligned}
& \mathrm{r}_{\mathrm{yx}} \text { or } \mathrm{r}_{\mathrm{xy}}= \frac{\sum_{i=1}^{n}\left(x_{i}-\bar{x}\right)\left(y_{i}-\bar{y}\right)}{\sqrt{\sum_{i=1}^{n}\left(x_{i}-\bar{x}\right)^{2} \sum_{i=1}^{n}\left(y_{i}-\bar{y}\right)^{2}}} \\
& \mathrm{r}=\frac{\operatorname{or} \sum_{i=1}^{n} x_{i} y_{i}-\sum_{i=1}^{n} x_{i} \sum_{i=1}^{n} y_{i}}{\sqrt{n \sum_{i=1}^{n} x_{i}{ }^{2}-\left(\sum_{i=1}^{n} x_{i}\right)^{2}} \sqrt{n \sum_{i=1}^{n} y_{i}{ }^{2}-\left(\sum_{i=1}^{n} y_{i}\right)^{2}}}
\end{aligned}
$$

Multiple regression analysis was performed through a model of panel data of 33 provinces in Indonesia during the 2010-2016 period. In general, three approaches were used in the regression model of panel data (Rosadi, 2011), namely:

1. Pooled Least Square, $E Q I=\beta_{0}+\beta_{1 i t} \operatorname{LnGRDP}+\beta_{2 i t} P D+u t_{i t}$;

2. Fixed Effect, EQI $=\alpha_{1}+\beta_{1 \mathrm{it}} \mathrm{LNGRDP}+\beta_{2 \mathrm{it}} \mathrm{PD}+\mathrm{c}_{\mathrm{i}}+\mathrm{d}_{\mathrm{t}}+\mathrm{e}_{\mathrm{it}}$;

3. Random Effect, EQI $=\beta_{0}+\beta_{1 \text { it }} L N G R D P+\beta_{2 i t} P D+w_{\text {it }}$

Several tests were performed to determine a good estimation technique for this research, including (1) Chow Test, which was used to determine the approximation between Polled Least Square and the Fixed Effect Model; (2) Multiplier Lagrange Test, used to choose an estimate between Pooled Least Square and Random Effect Model; (3) Haussman test, performed to determine the approximation between Fixed Effect Model and Random Effect model; and (4) Statistical Test. The statistical test was measured from F statistics, $t$ statistics, and coefficient of determination $\left(R^{2}\right)$.

\section{Result and Discussion}

In this study, we tested the best model and interpreted the results based on this model. The first step was analyzing the correlation between GRDP, Population Density, and EQI. The second step was identifying the best model for the three alternatives (common effect, fixed effect, and random effect). After determining the best model, we tested the hypothesis for the EKC model certainly the linear model presented by Ekins (1997). In the 
following section, the results of the analysis, selection of the best model, and discussion are presented.

\section{Estimation of the Correlation}

The correlation test was performed in this research to find out the strengths of the relationship between the observed variables. The correlation coefficient values obtained can be used to study the strengths of the relationship between variables, and the probability value obtained was used as a relationship explanatory between these variables. The results are as follows:

Table 1 Correlation Estimation for EQI

\begin{tabular}{lcc}
\multicolumn{1}{c}{ Variable } & Coefficient & Probability \\
\hline GRDP & -0.554 & 0.0000 \\
Population Density (PD) & -0.473 & 0.0000 \\
\hline
\end{tabular}

The Table 1 shows that the coefficient of tested variables is - (negative), indicating that as the GRDP and PD (Population Density) increase, the EQI decreases, and conversely as the EQI increases, the GRDP and PD will decrease. Furthermore, the GRDP coefficient value of -0.554 indicates a moderate relationship between the GRDP and EQI. PD and EQI with a coefficient value of $-0,473$ fall into the same category of moderate relationship. Then, the two variables show a significant probability of 0.0000 , this implies $\mathrm{H}_{0}$ is accepted or a connection between variables exists.

\section{Multiple Regression}

\section{Panel Data Model Estimation}

To find the most appropriate model, panel data regression was employed on three approaches; the Common Effect Model (ECM), the Fixed Effect Model (FEM), and the Random Effect Model (REM).

\section{Common Effect Model}

This model is the simplest way that attempts not to consider between time (time-series) and individual dimensions (cross-section). It combines time-series data and crosssectional data of a pool. The estimation results of this model are described as follows:

Table 2 Common Effect Model (CEM) Estimation

\begin{tabular}{|c|c|c|}
\hline Variable & Coefficient & Probability \\
\hline C & 119.9653 & 0.000 \\
\hline InGRDP? & -4.454518 & 0.000 \\
\hline PD? & -0.001368 & 0.000 \\
\hline R-squared & 0.374196 & \\
\hline Adjusted R-squared & 0.368706 & \\
\hline
\end{tabular}


The results of panel data regression of this model show that variables of Population Density (PD) and Gross Regional Domestic Product (GRDP) have a significant impact on the Environmental Quality Index (EQI). Meanwhile, the Adjusted R-Squared value is $36.87 \%$, implying that the independent variable can explain the dependent variable that is equal to $36.78 \%$, and the remaining $63.22 \%$ is explained by variables outside the model.

\section{Fixed Effect Model}

Individual differences are explained by the Fixed-Effect Model. These differences can be investigated through the dummy variable. The estimation results of this model are presented in Table 3.

Table 3 Fixed Effects Model Estimation Results

\begin{tabular}{|c|c|c|}
\hline Variable & Coefficient & Probability \\
\hline C & 235.1151 & 0.0000 \\
\hline InGRDP & -14.80981 & 0.0009 \\
\hline PD & 0.007023 & 0.4787 \\
\hline R-squared & 0.672860 & \\
\hline Adjusted R-squared & 0.616111 & \\
\hline
\end{tabular}

The regression results of this model indicate that the variable GRDP has a significant impact on the Environmental Quality Index (EQI). Meanwhile, the Population Density (PD) does not have any significant influence. An adjusted R-Squared value of $61.61 \%$ denotes that the independent variable can explain approximately $61.61 \%$ of the dependent variable, with the remaining $38.39 \%$ elaborated by variables outside the model.

\section{Random Effect Model}

This particular model is a model that can explain specific effects in each individual that are used as part of the random error component, which has no correlation with independent variables. The estimation results of this model are shown in Table 4.

Table 4 Random Effects Model Estimation Results

\begin{tabular}{|c|c|c|}
\hline Variable & Coefficient & Probability \\
\hline C & 126.0416 & 0.0000 \\
\hline InGRDP & -4.980457 & 0.0000 \\
\hline PD & -0.001261 & 0.0148 \\
\hline R-squared & 0.159443 & \\
\hline Adjusted R-squared & 0.152070 & \\
\hline
\end{tabular}

The regression values of this effect show that GRDP and Population Density (PD) have a significant impact on the Environmental Quality Index (EQI). Meanwhile, the Adjusted RSquared value is $15.94 \%$, implying that the independent variable can explain the dependent variable by $15.94 \%$, and the rest $84.06 \%$ is explained by variables outside the model. 


\section{The Selection of Panel Data Estimation}

Several tests were administered to determine the most appropriate model. The model options are Common Effect Model (CEM), Fixed Effect Model (FEM), and Random Effect Model (REM).

\section{Chow Test}

Chow Test is a method for determining the best model from the common effect model (CEM) and the fixed effect model (FEM). The following assumptions exist in this test interpretation: (1) $\mathrm{H}_{0}$ is accepted if $\mathrm{F}$-statistics $\langle\mathrm{F}$-table and probability value ( $\rho$-value) $>$ $0.05 ;(2) \mathrm{H}_{0}$ is accepted if F-statistics $>\mathrm{F}$-table and probability value $(\rho$-value $)<0.05$.

Table 5 Chow Test Results

\begin{tabular}{|c|c|c|c|}
\hline Effects Test & Statistics & d.f & Prob. \\
\hline Cross-section $\mathrm{F}$ & 5.591833 & $(30.196)$ & 0.0000 \\
\hline Cross-section Chi-square & 149.837643 & 32 & 0.0000 \\
\hline
\end{tabular}

The Table 5 shows that the cross-section $\mathrm{F}$ probability value is 0.0000 or smaller than 0.05 . This means that $\mathrm{H}_{0}$ is rejected while $\mathrm{H}_{1}$ is accepted, indicating that the fixed effect model (FEM) outperforms the common effect model (CEM) in the estimation process.

\section{Hausman Test}

The Hausman test is employed to select which of the random effect model (REM) and fixed effect model (FEM) is the best. The following assumptions are applied in the Hausman test: (1) $\mathrm{H}_{0}$ is accepted if the Hausman statistical value<chi-square value and the probability value ( $\rho$-value) $>0.05 ;(2) \mathrm{H}_{1}$ is rejected if Hausman statistical value $>$ chi-square and probability value ( $\rho$-value) $<0.05$.

Table 6 Hausman Test Results

\begin{tabular}{rccc}
\hline Test Summary & Chi-Sq Statistic & Chi-Sq. d.f & Prob \\
\hline Cross-section random & 5.377823 & 2 & 0.0680 \\
\hline
\end{tabular}

Based on the results of Table 6 , the Hausman test represents a random cross-section probability value of 0.0680 , which is $>0.05$. It implies that the random effect model (REM) is the best model to use in the estimation process.

Lagrange Multiplier Test

The Lagrange Multiplier (LM) test is performed to select the best approach between REM and CEM. The distribution of chi-square with the degree of freedom ( $\mathrm{df}$ ) is used as a basis for the LM test. The following conditions are applied in the hypothesis testing: (1) $H_{0}$ is accepted if the Breusch-Pagan probability value ( $\rho$-value) $>0.05 ;(2) \mathrm{H}_{1}$ is rejected if the Breusch-Pagan probability value ( $\rho$-value) $<0.05$. 
Table 7 Lagrange Multiplier Test Results

\begin{tabular}{lcc}
\multicolumn{1}{c}{ Hypothesis Test } & Cross-section & Prob \\
\hline Breusch-Pagan & 96.06440 & 0.0000 \\
\hline
\end{tabular}

According to the results, the Lagrange Multiplier (LM) test shows the value of BreuschPagan probability of 0.0000 , which is smaller than 0.05 . It means that REM can be the best model to use in the estimation process.

\section{Hypothesis Testing}

Simultaneous Coefficient Test ( $F$ test)

The $F$ test is used to determine the independent variables. The results show that Population Density (PD) and Gross Regional Domestic Product (GRDP) have a significant impact on the dependent variable, which is the Environmental Quality Index (EQI). The results of the simultaneous coefficient test are shown in Table 8.

Table 8 F Test

\begin{tabular}{lll}
\hline & F-statistics & 21.62436 \\
\hline Prob (F-statistics) & 0.000000 \\
\hline
\end{tabular}

The Table 8 presents the prob value (F-Statistics) is 0.00 . It shows that at a significant level of 0.05 , the value of prob (F-Statistics) is smaller than 0.05 . Therefore, it can be concluded that the GRDP and PD have an impact on the Environmental Quality Index (EQI).

Partial Test (t-test)

The t-test is used to examine the spatial effect of independent variables, which are PD and GRDP on EQI.

Table 9 T-test Results

\begin{tabular}{|c|c|c|}
\hline Variable & t-Statistic & Probability \\
\hline $\mathrm{C}$ & 126.0416 & 0.0000 \\
\hline InGDRP & -4.980457 & 0.0000 \\
\hline PD & -2.456560 & 0.0148 \\
\hline
\end{tabular}

The followings are the results of the tests for each hypothesis: (1) Gross Regional Domestic Product (GRDP) variable has a calculated value of (4.980457) $>t_{\text {table }}(1.660)$, meaning that each independent variable has a significant impact on the dependent variable; (2) Population Density Variable (PD) has a t-statistic value (2.456560)> $t_{\text {table }}(1.660)$, implying that independent variable has a significant impact on the dependent variable.

\section{Coefficient of Determination Test $\left(R^{2}\right)$}

To measure the effect of GRDP and PD on EQI, the coefficient of determination $\left(R^{2}\right)$ test is conducted. The Table 10 features the results of the coefficient of determination test: 
Table 10 Coefficient of Determination Test

\begin{tabular}{cc} 
R-squared & 0.159443 \\
\hline Adjusted R-squared & 0.152070 \\
\hline
\end{tabular}

The results show the Adjusted R-squared value of 0.152070. It indicates that independent variables, namely GRDP and PD can explain $15.21 \%$ of the Environmental Quality Index (EQI). Meanwhile, the remaining $84.79 \%$ are described by factors outside this model.

\section{Data Interpretation and the Discussion of Panel Data}

The Random Effect Model (REM) regression estimation is calculated based on the panel data method and is processed using Eviews 9 software. The results are shown in the Table 11. From the regression model, the following equation is drawn:

$$
\begin{array}{ll}
\mathrm{EQI}_{\mathrm{it}} & =\beta_{1}+\beta_{2} \operatorname{lnGRDP}+\beta_{3} \mathrm{PD}+\varepsilon_{\text {it }} \\
\mathrm{EQI} & =126.0416-4.980457 \operatorname{lnGRDP}-0.001261 \mathrm{PD}
\end{array}
$$

where:

$\mathrm{EQI}=$ Environmental Quality Index (unit), InGRDP = Log Gross Regional Domestic Product (IDR/ year), PD = Population Density (\%)

\begin{tabular}{|c|c|c|}
\hline Variable & Coefficient & Probability \\
\hline C & 126.0416 & 0.0000 \\
\hline GRDP? & -4.980457 & 0.0000 \\
\hline PD? & -0.001261 & 0.0148 \\
\hline R-squared & 0.159443 & \\
\hline Adjusted R-squared & 0.152070 & \\
\hline
\end{tabular}

Table 11 Estimation Results of Random Effects Model

The interpretations of the results of the Random Effect Model (REM) regression using the panel data method shows that the constant partial regression coefficient value is 126.04 and the value of $t$-statistic is 9.90 , where the table value is 1.653 . This means that $t-$ statistic is greater than the $t$-table $(9.90>1.653)$. The constant coefficient is statistically significant with a probability value of 0.00 . Economic growth is statistically has a significant impact on environmental quality.

This condition suggests that when the level of economic growth and population density in 33 Provinces in Indonesia is constant or assumed to remain constant, the quality of the environment will reach a constant rate. In other words, if the level of economic growth and population density is constant, the environmental quality will remain at 126.04 . Further, this can be elaborated as follows:

\section{The Effect of Economic Growth (GRDP) on Environmental Quality (EQI)}

The data analysis results show that partially the level of economic growth represented by gross regional domestic product (GRDP) has a significant negative impact on the environmental quality with the probability value of $0.00<0.05$. These results illustrate that 


\author{
Wafiq \& Suryanto \\ The Impact of Population Density and Economic Growth ...
}

if economic growth in Indonesia, particularly in the 33 provinces, increases by one unit, environmental quality is likely to decrease by 4.98 percent per unit, assuming that all other independent variables remain constant or fixed, and vice versa.

This research relies on the linear model because the independent variable for GRDP is not in quadratic form.

These results are consistent with those of Ong and Sek (2013), Yustisia and Sugianto (2014), Lee and Oh (2015), and Damayanti and Chamid (2016). Economic growth in the study areas shows an unsustainable trend. The relationship between economic growth and development to changes in environmental quality, which continues to decline, is shown by the occurrence of global warming and extreme climate change.

\title{
The Effect of Population Density on Environmental Quality (EQI)
}

This study proposes that the population density has a significant negative impact on the environmental quality with the probability value of $0.0148<0.05$. These illustrate that if the population density in 33 Indonesian provinces increases by one unit, the environmental quality will decline by 0.001 percent per unit, considering that other independent variables are fixed or consistent, and vice versa.

The present study shows a negative correlation between population density and environmental quality. This notion corresponds with research by Zuhri (2014), which discovered that population density would result in increased air emissions in Indonesia. Air emissions are one indicator of the quality of the environment of a region. Furthermore, research by Das and Paul (2014); Gul et al. (2015), and Damayanti and Chamid (2016), also underpinned similar findings that population density increased pollution.

\section{Conclusion}

Correlation analysis between GRDP and EQI shows a negative trend. A negative sign indicates that an increase in domestic products will be accompanied by a decrease in environmental quality. Sources of PDRB contributors in Indonesia, particularly from mining, industry, and even services also worsen the condition of environmental quality. The relationship between population density and EQI is negative. The increase in population density is followed by the deterioration of environmental quality. High land requirements for industry, housing, and transportation are increasingly worsening the environmental quality.

The Simon Kuznets EKC curve is assumed to apply in Indonesia based on the estimation results of panel data regression for GRDP and population density on EQI. The model used - Random Effect Model - has a negative impact on the EQI. As Indonesia's population grows, so does the pressure on the environment. 


\author{
Wafiq \& Suryanto \\ The Impact of Population Density and Economic Growth ...
}

Regulations governing the use of natural resources are already in place, but their implementation in the field is not optimal yet. Regulations on buildings, industry, housing, roads, and physical buildings that have other significant impacts must be thoroughly implemented. Compliance with environmental regulations can ensure more efficient use of natural resources. Then, to reduce more environmental pollution, the government must control the waste processing of each production process of a company in addition to enacting strict policies. Furthermore, population control through family planning program campaigns is required. With a controlled population, the need for food, shelter, and other facilities can be fulfilled.

\title{
Recommendation
}

The results of this study suggest that policymakers tighten environmental permits. This study still has some limitations regarding the study of the high economic growth with an increasing index. According to the EKC theory, once a state reaches a certain level of per capita income, it will realize that quality of life is an important aspect to consider.

\section{References}

Ahmad, M. H., Azhar, U., Wasti, S. A., Inam, Z., \& Ghani, N. (2005). Interaction between population and environmental degradation. The Pakistan Development Review, 44(4), 1135-1150. Retrieved from http://www.jstor.org/stable/41261148

Beckerman, W. (1992). Economic growth and the environment: Whose growth? whose environment? World Development, 20(4), 481-496. https://doi.org/10.1016/0305750x(92)90038-w

Bouznit, M., \& Pablo-Romero, M. del P. (2016). CO2 emission and economic growth in Algeria. Energy Policy, 96, 93-104. https://doi.org/10.1016/j.enpol.2016.05.036

Damayanti, R., \& Chamid, M.S. (2016). Analisis Pola Hubungan PDRB Dengan Faktor Pencemaran Lingkungan Di Indonesia Menggunakan Pendekatan Geographically Weighted Regression (GWR). Jurnal Sains dan Seni ITS, 15(1), 7-12. Retrieved from https://ejurnal.its.ac.id/index.php/sains seni/article/view/14170

Das, A., \& Paul, S. K. (2014). CO2 emissions from household consumption in India between 1993-94 and 2006-07: A decomposition analysis. Energy Economics, 41, 90-105. https://doi.org/10.1016/j.eneco.2013.10.019

Ekins, P. (1997). The Kuznets curve for the environment and economic growth: examining the evidence. Environment and Planning A: Economy and Space, 29(5), 805-830. https://doi.org/10.1068/a290805

Gujarati, D.N., \& Porter, D.C. (2009). Basic econometrics. 5th Edition. New York: McGraw Hill Inc.

Gul, S., Zou, X., Hassan, C. H., Azam, M., \& Zaman, K. (2015). Causal nexus between energy consumption and carbon dioxide emission for Malaysia using maximum entropy bootstrap approach. Environmental Science and Pollution Research, 22(24), 1977319785. https://doi.org/10.1007/s11356-015-5185-0

Hassan, S. A., Zaman, K., \& Gul, S. (2015). The relationship between growth-inequalitypoverty triangle and environmental degradation: unveiling the reality. Arab Economic and Business Journal, 10(1), 57-71. https://doi.org/10.1016/j.aebj.2014.05.007 
Hitam, M. B., \& Borhan, H. B. (2012). FDI, Growth and the environment: impact on quality of life in Malaysia. Procedia - Social and Behavioral Sciences, 50, 333-342. https://doi.org/10.1016/i.sbspro.2012.08.038

Jindal, R., Kerr, J. M., \& Carter, S. (2012). Reducing poverty through carbon forestry? impacts of the N'hambita community carbon project in Mozambique. World Development, 40(10), 2123-2135. https://doi.org/10.1016/j.worlddev.2012.05.003

Lee, S., \& Oh, D.-W. (2015). Economic growth and the environment in China: Empirical evidence using prefecture level data. China Economic Review, 36, 73-85. https://doi.org/10.1016/i.chieco.2015.08.009

Mor, S., \& Jindal, S. (2017). Estimation of environmental Kuznets curve and Kyoto parties: a panel data analysis. International Journal of Computational Engineering \& Management, 15(1), 5-9.

Narayan, P. K., Saboori, B., \& Soleymani, A. (2016). Economic growth and carbon emissions. Economic Modelling, 53, 388-397. https://doi.org/10.1016/j.econmod.2015.10.027

Ong, S. M., \& Sek, S. K. (2013). Interactions between economic growth and environmental quality: panel and non-panel analyses. Applied Mathematical Sciences, 7, 687-700. https://doi.org/10.12988/ams.2013.13062

Ozturk, I., \& Acaravci, A. (2010). CO2 emissions, energy consumption and economic growth in Turkey. Renewable and Sustainable Energy Reviews, 14(9), 3220-3225. https://doi.org/10.1016/i.rser.2010.07.005

Panayotou, T. (1993). Empirical tests and policy analysis of environmental degradation at different stages of economic development. World Employment Programme Research. International Labour Organization. Retrieved from http://www.ilo.org/public/libdoc/ilo/1993/93B09 31 engl.pdf

Rosadi, D. (2011). Analisis ekonometrika \& runtun waktu terapan dengan $r$. Yogyakarta: Andi. Safriwan, S., \& Idris, I. (2020). Pengaruh globalisasi kepadatan penduduk dan pertumbuhan ekonomi terhadap degradasi lingkungan di Indonesia. Jurnal Kajian Ekonomi dan Keuangan, 2(4), 1-8. Retrieved from http://ejournal.unp.ac.id/students/index.php/epb/article/view/10384

Statistics Indonesia (BPS). (2020). Gross Regional Domestic Product of Provinces in Indonesia constant prices in 2010 (2010-2016). Retrieved from https://www.bps.go.id/

Todaro, M.P., \& Smith, S.C. (2011). Pembangunan ekonomi. Jakarta: Erlangga.

Todaro, M.P., \& Smith, S.C. (2015). Economic Development, 12th Edition. Harlow: Essex Pearson Education Limited.

United Nations. (2017). The sustainable development goals report. United Nations Publications. Retrieved from https://unstats.un.org/sdgs/files/report/2017/thesustainabledevelopmentgoalsreport 2017.pdf

Yustisia, D., \& Sugiyanto, C. (2014). Analisis empiris Environmental Kuznets Curve (EKC) terkait orientasi energi. Jurnal Ekonomi \& Studi Pembangunan, 15(2), 161-170. Retrieved from https://journal.umy.ac.id/index.php/esp/article/view/1232

Zuhri, M. S. (2014). Pengaruh faktor-faktor demografi terhadap emisi udara di Indonesia. Jurnal Ilmu Ekonomi dan Pembangunan, 14(2), 13-37. Retrieved from https://jurnal.uns.ac.id/jiep/article/view/9880 